\title{
THE OSTROGOTHIC KINGDOM IN THE OLD ENGLISH BOETHIUS AND THE GERMANIC MYTH OF ORIGIN IN ANGLO-SAXON ENGLAND
}

The Old English Boethius, the vernacular translation of Anicius Manlius Severinus Boethius's Consolatio of Philosophae, is attributed to King Alfred the Great (849899 A.D.). He is credited with authorship in the two prefaces that accompany the work surviving in two versions, one entirely in prose, the other alternating verse and prose sections, as Boethius's prosometric original does. The most recent editors of the Old English Boethius claim that the Old English prose Boethius precedes the vernacular prosometric version. ${ }^{1}$ When it comes to Alfred's authorship, it cannot go unnoticed that the identity of both prefaces as Alfredian translations have been a matter of controversy among literary historians, some of whom doubt Alfred's authorship of the Old English Boethius. Malcolm Godden observes that, unlike other preface that accompany Alfred's works, both the prose and the metrical preface refer to the king in the third person. ${ }^{2}$ Nicole Guenther Discenza doubts that king Alfred composed the prose preface to Boethius because the preface defeats the purpose served by other Alfredian prefaces. ${ }^{3}$ Discenza stays clear of Sisam's view that the composer of the preface worked a forger or fabricator. She suggests that "an admirer, rather than fabri-

* Jacek Olesiejko is a lecturer at the University of Adam Mickiewicz and Wyższa Szkoła Języków Obcych im. Bogusława Lindego in Poznań. His interests include Old English literature and culture, gender studies and history of emotion.

1 Malcolm Godden, Susan Irvine, eds., The Old English Boethius: An Edition of the Old English Versions of Boethius's De Consolatione Philosphae, 2 vols (Oxford: Oxford University Press, 2009), 33.

2 Godden, Irvine, The Old English Boethius, 141.

3 Nicole Guenther Discenza, "Alfred the Great and the Anonymous Prose Proem to the Boethius", The Journal of English and Germanic Philology 107 (2008): 58. 
cator or forger, could have seen the Prose and Verse Prefaces to the Pastoral Care and noted that every other Meter in Boethius has a corresponding prose in the prose-only version". 4

The inclusion into the Old English Boethius of the two prefaces that argue Alfred's authorship cause a fissure that, at a first glance, might well tear the unity of the work apart. A theme that informs the structure and conception of the vernacular version is the appropriately Christian notions of kingship and royal conduct. It is evident that, in contrast to the original source, the Old English Boethius is ostensibly didactic and provides a Christian focus on the roles of kings and their subjects. On the one hand, Old English Boethius supplies its source with a conceptual framework that structures a Christian understanding of kingship. On the other, reflections on political authority found in the source are refracted in its vernacular rendition through ecclesiastical position that flouts the authority of earthly rule on the grounds of its corruption. Thus, Alfred's authorial presence in the translation provides a tension that haunts the Old English Boethius, a tension produced by the royal authority of the text and by the persistent critique of secular rule. Alfred the author situates himself uncomfortably on the defensive; his secular authority is questioned throughout the work.

Another fissure is found in the introductory portion of the work, which is wholly of the translator's contriving. The introductory portion of Boethius provides a focus on two Germanic rulers of Rome, Alaric and Theodoric, whose successive reigns are presented in Old English Boethius to cause the fall of Rome from its position of a model Christian state. While critics often argue that the Old English Boethius presents a positive view of the Germanic origins of the Anglo-Saxons, this notion needs a profound reconsideration. Stephen Harris takes pains to show that the Old English adaptation of Orosius's World History "contributed to the process by which Anglo-Saxons began to understand themselves as a single people continued both ethnically and religiously" and "can be explained as an ethnic (especially Anglo-Saxon) response to Christian history; that is, a sense of Germanic community shapes the Latin into a story of the origins of Christendom". ${ }^{5}$ Harris further argues that "the Orosian inheritance, ... with the respect to Alfredian World History, emphasised the foundational role of Alaric the Goth in the perceived Germanic imperial origins of Christendom". ${ }^{6}$ However, considering the brunt of the textual evidence that the present article gathers from the Old English Boethius it must be stated that such a concep-

4 Nicole Guenther Discenza aims at demonstrating that Alfred was not the author of the prose preface by means of linguistic and stylistic evidence. See Discenza, "Alfred the Great", 60.

5 Stephen J. Harris. Race and ethnicity in Anglo-Saxon literature. (New York and London: Routledge, 2003), 91.

6 Harris, Race, 131. 
tion of history is alien to the author of the Old English Boethius. In fact, the translator makes a case for the discontinuity between the Germanic origins of Anglo-Saxons and their role in world Christian history, which is ostensibly emphasised in the adaptation. The negative view on the Ostrogothic kings is, for example, at odds with the West-Saxon pedigree, whose dramatis personae share origins with both Alaric and Theodoric.

The treatment of the historical material in the Old English Boethius indicates that its author contests the Germanic notions of origins that underlie the ideology of hegemonic continuity exhibited in both Anglo-Saxon vernacular poetic practices and Anglo-Saxon royal genealogies that chronicle the legacy of regal authority passed down from euhemerised pagan divinities like Woden. The present paper makes a case that the figure of Theodoric in the proem to the Old English Boethius engages the text in a dialogic relationship with earlier Old English discourses, contesting and rivalling earlier tradition. The Bakhtinian term of dialogism is helpful in explicating the memory of a Germanic past in the Old English Boethius, which forms an unexplored and ambiguous terrain of Alfredian literature.

Earlier studies have shed much light on the influence that early medieval grammatical and rhetorical as well as early medieval translation theory exerted on the Old English Boethius. This study turns to an understanding of early medieval translation offered by Rita Copeland in her Rhetoric, Hermeneutic and Translation to argue that the prefaces to the Old English Boethius are informed by the rhetorical and hermeneutic strategies of displacement of a source that characterised the early medieval practices of vernacular translation. Copeland's claim is that early medieval translation is influenced by "the relationship of translation to the commentary tradition."

Medieval arts commentary does not simply "serve" its "master" text: it also rewrites and supplants them... It [translation practice] takes over the function of commentary on the auctores, and in so doing replicates the characteristic move of academic exegesis, that of displacing the very text that it proposes to serve. ${ }^{?}$

Copeland demonstrates that early medieval translation practice looks to antique translation models, where Roman translation "offered a perfect platform for contesting the pre-eminence of Greek culture" and goes on to argue that "translation in Roman theory is figured as a pattern of transference, substitution, and ultimately displacement of the source". ${ }^{8}$ This paper brings attention to a surprisingly reversed

7 Rita Copeland, Rhetoric, Hermeneutics, and Translation in the Middle Ages: Academic traditions and vernacular texts (Cambridge: Cambridge University Press, 1991), 3-4.

8 Copeland, Rhetoric, 44. 
notion of contest and displacement pervades the dialogic dynamic of the past and the present that informs Old English Boethius. In the Old English Boethius, it is the foreign Latinate culture that masters and supplants the ancient Germanic lore. Given the entire oral and textual tradition, which amply testifies to the importance attached to Germanic myth and legend in Anglo-Saxon England, the Old English Boethius is designed to contest the primacy of the myth of Germanic origin for Anglo-Saxon culture by downplaying the role that Germanic rulers played in Christian history.

The scheme that guided the translation of the Boethius also defies a Bourdiean model of translation that Nicole Guenther Discenza adopted for her unrivalled analysis of the work. She applies therein Pierre Bourdier's concepts of adequacy and acceptability "Adequacy is the degree to which a translated text reflects its source at any level from the vocabulary, style and syntax to imagery, structures, and themes. Acceptability is the degree to which the world matches standards of which native texts are held, again ranging from vocabulary to higher structural and conceptual levels". 9 In The King's English (2005), Discenza proves that Alfred the translator was successful at mastering the Latin text of Consolatio and adapting it to the needs and horizons that his audience represented. The proem to the Boethius, however, constitutes a broad reinterpretation of Alfred and his audience's past that was not compatible with the norms proposed by Copeland's and Discenza's models of translation.

It is argued in the present article that the treatment of the Ostrogothic history in the Old English Boethius revisits the theme of origin for Anglo-Saxon Christianity, earlier articulated in Bede's Historia Ecclesiastica Gentis Anglorum (731 A.D.), with a view to positing a particular role for kingship and state of Alfred's (as well his successor's) England. Cultural programme of translation, which Alfred the Great initiated, supports translatio studii, transfer of learning, from Latin literary culture to AngloSaxon vernacular cultural practice. As ruler and translator of Consolatio, Alfred acknowledges the weight and significance of the inheritance of Rome, reviving the theme found in Bede's Historia. The treatment of Germanic past in Boethius makes this inheritance outweigh the memory of Germanic past and the myth of Germanic origin for Anglo-Saxons, the myth that prevailed in Old English vernacular culture.

The general disregard for Germanic hegemony over Rome in the Old English Boethius is outweighed by the high esteem in which Germanic gods and rulers are generally held in Anglo-Saxon genealogical lists and historiography. The myth of Germanic origin had been repeatedly evoked in Anglo-Saxons writings before Alfred. It was in turn revived in Anglo-Saxon genealogical lists, where Woden was euhem-

9 Nicole Guenther Discenza, The King's English: Strategies of Translation in the Old English Boethius (New York: State University of New York Press), 2005. 
erised as a royal protoplast of Kings Ida of Northumbria and Penda of Mercia in the Anglo-Saxon Chronicle. While King Æthelwulf of Wessex's (King Alfred's father) genealogy is extended to include Adam, it does not displace Woden from his position of forbear..$^{10}$ Also, Asser commences his Latin Life of Alfred with a royal pedigree that includes Woden. As Nicholas Brooks observes, the Anglo-Saxons found both genealogical lists and heroic poetry to be "constructs reflecting the wish of royal households to define a kernel of 'tradition' which would provide an identity for the people under the leadership of the ruling house". ${ }^{11} \mathrm{H}$. Moisl argues the pagan and Germanic, rather than ecclesiastical, origin and cultivation of the Anglo-Saxon genealogical lists because they feature the Germanic god Woden as the forebear of all Anglo-Saxon dynasties. He goes on to claim that the lists were "maintained in the form of orally transmitted narrative traditions" and that "these traditions were cultivated by a court poet known to the Anglo-Saxons as the scop". ${ }^{12}$ The case that H. Moisl makes may well be strengthened by Asser's report in his Vita, which depicts the young Alfred as having competed with his elder brother for a book of vernacular poetry, kept by his mother. Accordingly, in narrating the reigns of Alaric and Theodoric, the Old English Boethius engaged in a dialogue with long-established vernacular traditions that had been central to the identity of Anglo-Saxons as gens.

It is also notable that Theodoric must have been familiar to the Anglo-Saxon audiences of secular poetry, since two Old English poems, Widsith and Deor, share the memory of Theodoric from a heroic perspective.

10 "Ethelwulf was the son of Egbert, Egbert of Ealhmund, Ealhmund of Eafa, Eafa of Eoppa, Eoppa of Ingild; Ingild was the brother of Ina, king of the West-Saxons, who held that kingdom thirty-seven winters, and afterwards went to St. Peter, where he died. And they were the sons of Cenred, Cenred of Ceolwald, Ceolwald of Cutha, Cutha of Cuthwin, Cuthwin of Ceawlin, Ceawlin of Cynric, Cynric of Creoda, Creoda of Cerdic, Cerdic of Elesa, Elesa of Esla, Esla of Gewis, Gewis of Wig, Wig of Freawine, Freawine of Frithugar, Frithugar of Brond, Brond of Balday, Balday of Woden, Woden of Frithuwald, Frithuwald of Freawine, Freawine of Frithuwualf, Frithuwulf of Finn, Finn of Godwulf, Godwulf of Great, Great of Taetwa, Taetwa of Beaw, Beaw of Sceldwa, Sceldwa of Heremod, Heremod of Itermon, Itermon of Hathra, Hathra of Hwala, Hwala of Bedwig, Bedwig of Sceaf; that is, the son of Noah, who was born in Noah's ark: Laznech, Methusalem, Enoh, Jared, Malalahel, Cainion, Enos, Seth, Adam the first man, and our Father, that is, Christ. Amen". Bob Carruthers, The Anglo-Saxon Chronicle (Barnsley: Pen and Sword Books Limited, 2013), 101-102.

11 Nicholas Brooks, Anglo-Saxon Myths: State and Church 400-1066 (London and Rio Grande: The Hambledon Press, 2000), 79.

12 Hermann Moisl, “Anglo-Saxon Royal Genealogies and Germanic Oral Tradition”, Journal of Medieval History 7 (1981), 228. "The Life of Ethelberht says that the king's singers recited carmina (pl.) about his royal line, which suggests a more or less extensive body of material, and The Life of Guthlac speaks, also in the plural, about valida pristinorum heorum facta and the deaths of antiquorum regum stirpis suae, which shows that Mercian dynastic historical encompassed a sequence of kings". Ibidem, 234. 
Đeodric ahte pritig wintra

Mæringa burg — pæt wæs monegum cup.

Pæs ofereode, pisses swa mæg!

Theodoric ruled over the kingdom of the Ostrogoths for thirty years. That passed over; this also may.

(18-20)

Here the reference to Theodoric provides a reflection on mortality and vanity of human achievement that pervades Deor's lament over his own fall from grace at a royal hall. Widsith alludes to Theodoric's reign over the Franks (Peodric weold Froncum [Theodoric ruled over the Franks], 1. 24). These references to Theodoric not only testify to the knowledge which Anglo-Saxon had of him, but also make manifest the fact that the memory of Theodoric belongs to traditional lore about the Germanic peoples, with whom the Anglo-Saxons shared origins. Hence, it is tempting to suggests that the amplified narrative of his heretical rule in the Old English Boethius is designed to outweigh the backdrop of the respect for Theodoric in Anglo-Saxon poetic tradition.

The memory of Alaric that emanates from Germanic oral tradition is balanced by Latin historiography. The Old English translation of Orosius World History transmits a more detailed historical outline of Alaric and Rædgota's rule over Rome.

Raðe pæs Alrica wearð christen, ond Rædgota hæpen purhwunade on dæghwamlice wæs blotende diofolgildum mid monslihtum.... Nugiet eow Romane mæg gescomian, cwæð Orosius, pæt ge swa heanlic gepoht sceoldon on eow geniman for anes monnes ege ond for anes monnes geblote, pæt ge sædon pæt pa hæðnan tide waeron beteran ponne christnan, ond eac pæt eow selfum wære betere pæt ge eowerne cristendom forleten on to pæm hæðeniscan peawum fenge pe eowre ieldran ær beeodon. Ge magon eac gepencan hu hean he eft wearp his geblota ond his diofolgilda pe he on gelifde (Orosius VI.xxxvii).

Quickly Alaric became Christian while Rædgota remained heathen and each day he sacrificed human blood to the devils. It is shameful, says Orosius, that you were so afraid of one man's oppression that you said that the heathen were better than Christians. It was more profitable for you to forsake Christianity and embrace heathen practices that your ancestors had observed. You should reflect that this oppressor incurred many misfortunes on account of his devilish worship. ${ }^{13}$

13 The text is taken from Janet Bately, The Old English Orosius (London: Oxford University Press, 1980). Translation into modern English is mine. 
Although Alaric converts to Christianity, Radagaisus (Rædgota) remains pagan. Radagaisus comes under scrutiny from Christian perspective that the Orosius translator maintains; his Germanic religious practice brings violation to the Christian notion of civilised behaviour.

The very fact that Alfred is named the translator of Boethius means that the Old English Boethius's reflections on kingship and political authority will have carried the weight of royal authority and that the presentation of Alaric and Theodoric must be related intertextually to wider textual traditions that other Alfredian writings supported and continued. The prefaces to the Old English Boethius exploit Alfred's authority to provide a perspective from which to interpret the interconnected themes of royal power, legitimacy and origins which emerge in the translation. ${ }^{14}$ It is important to note that both prefaces present non-complementary statements of the authorial intention behind the translation. Unlike in other prefaces that accompany other allegedly Alfredian translations, Alfred does not address the audience in the first person. The prose preface states that "Alfred wæs wealhstod pisse bec" [the translator of this book] (p. 2), while in the verse preface, written to accompany the later prosometric version, the audience is addressed, prosopopeically, by the book itself: "pus Ælfred us eald-spell reahte, /Cyning West-sexna" [Thus King Alfred, the king of the WestSaxons, told us an ancient story] (verse 1, 1-2). Another marked difference is that according to the prose preface the translation is King Alfred's personal exercise in piety in a taxing period of war and is largely apologetic in tone. King Alfred is to be excused for imperfection on the ground of his involvement in the political events.

The expanded verse preface reformulates the earlier authorial statement of the role which the text is to play for its audience. The preface is framed by the rhetorical device of prosopopeia. At the beginning, the book speaks of its having been written by the king. It also communicates with the audience by means of oral formulas: "ic sceal giet specan/ folcupne raede" [I shall speak well-known advice 8]. The preface proclaims Alfred's desire to entertain the audience with a work of alternating verse and prose. The statement prefigures one of the most recurring themes of the adapta-

14 According to the most recent editors of Boethius, the prosometric version of the adaptation is best dated to the mid-tenth century. The only copy of the prosometric version is found in London, British Library, Cotton Otho A.vi. "The general character of the script suggests a date around the middle of the tenth century, though the tendency to roundness might suggest a date a little after the middle, when Caroline influence begin to show", Godden, Irvine, The Old English Boethius, 22. Godden and Irvine maintain that the prosometric version was composed after the prose version. "The prose rendering of the Latin metres is in almost every case much closer to the Latin than the verse rendering is, with the latter characteristically being more expansive and often repetitive, and the prose rendering rarely uses the poetic diction or alliteration that marks the verse. If the prose were based on the verse, it would be hard to explain how the reviser managed so successfully to remove the characteristic language of verse and so much of the expansive detail”. Ibidem, 44. 
tion: that of pride. The aesthetic pleasure to be derived from the expanded version of Boethius is at its greatest when the audience recognises the moral lesson found in the story. Neglecting the book's moral theme on the part of the audience is cast as a symptom of pride. Secondly, the preface imagines an audience ready to listen to advice. While the prose preface imagines Alfred's Boethius as a book to be perused privately, the verse preface depicts Boethius as a book that is important for a community. The second preface offers an apt illustration for Robert Stanton's remark that Alfred casts himself as "an eloquent king who possesses the power to move and persuade his subjects" by means of his literary oeuvre. ${ }^{15}$

The prefaces are followed by proems, which provide a historical outline that frames Boethius career and his tragic demise. The prose version found in Oxford, Bodleian Library, Bodley 180 (2079) preserves a short prose proem. Here Alfred introduces material not found in the source, which never mentions the sack of Rome at the hands of Alaric and Rædgota in 410 A.D.

On ða ðære tide the Gotan of Sciððiu mægðe with Romana rice gewin up ahofon, ond mid heora cyningu, Rædgota ond Eallerica wæron hatne, Romane burig abrecon, ond eall Italia rice ðæt is betwux ðam muntu and Sicilia pam ealonde in anwald gerehton, and pa after pa forespreccnan cyningu beodric feng to pam pilcan rice.

At that time, the Goths made war on Rome and, together with their kings that were called Rædgota and Alaric, invaded Rome. They occupied the entire Italia, which extended from the mountains to Sicily. These kings were followed by Theodoric in line of succession. ${ }^{16}$

The proem is historically inaccurate as it presents Theodoric as Alaric's immediate successor; in reality. a span of over six decades separates the reigns of historical rulers. This suggests, as Janet Bately claims, the influence of the Old English Orosius. ${ }^{17}$

While the poetic version from the later prosometric version found in London, British Library, Cotton Otho A, vi preserves the prose proem, it is followed by an extended poetic rendering of it, supplying a more complex picture of Germanic invaders, the picture which presents their leadership as a threat to Rome upheld as an epitome of Christian empire. Christians as though they are, Alaric and Theodoric are castigated

15 Robert Stanton, The Culture of Translation in Anglo-Saxon England (Cambridge: D.S. Brewer, 2002), 91.

16 The quotation comes from Walter John Sedgefield, King Alfred's Old English version of Boethius De Consolatione Philosophae, (Oxford: Clarendon Press, 1899). Translation into modern English is mine.

17 Janet Bately, The Old English Orosius (London: Oxford University Press, 1980), xcii. 
for their adherence to Arian heresy, the adherence which causes a radical discontinuity in the transmission of the intellectual and political inheritance of Rome. ${ }^{18}$ As the prose proem, the verse proem telescopes Alaric's sack of Rome and Theodoric's rule over Italy into a succession of calamities that inaugurates the Germanic usurpation of the Roman Empire and reinforcing the impression that their regime infects Christianity, ushering in a new era of Arian heresy.

Đa wæs Romana rice gewunnen,

Abrocen burga cyst; beadu-rincum wæs

Rom gerymed. Rædgot and Aleric

Foron on ðæt fæsten; fleah casere

Mid pam apelingum ut on Crecas.

Ne meahte pa seo wea-laf wige forstandan

Gotan mid guðe; gio-monna gestrion

Sealdon unwillum epel-weardas,

Halige aðas; waes gehwæðres waa.

Peah waes mago-rinca mod mid Crecum,

Gif hi leod-fruman læstan dorsten.

Then the kingdom of the Romans was conquered, sacked was the best of cities. It was open to warriors Rædgota and Alaric came to the stronghold, while the Caesar fled accompanied by his retainers to Greece. The remnant of the army failed to withstand the attack of the army of Goths. The guardians of homeland gave away the inheritance of their ancestors; they made sacred promises. It was woeful in both respects. Still, their hearts were with the Greeks if they had courage to remain with their leader (Meter 1, 17-27). ${ }^{19}$

Alaric Amaling and Radgais are depicted as barbarians putting the ancient romanitas to a violent and abrupt end. Alaric was baptised and is described as "Criste geconodon" [committed to Christ] (Meter 1, 32). However, "wæs pam apelinge Arrianes gedwola leofre ponne drihtnes æ" [the heresy of Arius was dearer to that prince

18 Arianism was a heresy particularly outrageous to Anglo-Saxon audiences made familiar with the Pelagian heresy not only through Bede's Latin Historia Ecclesiastica, but also through its Old English translation associated with Alfredian translations. Its founder Pelagius - after his name the heresy is also known as pelagianism - was British. Bede claims that a few years before Germanic tribes commenced their settlement in England, "the Pelagian heresy, introduced by Agricola, the son of the Pelagian bishop Severianus, had corrupted the faith of Britain with its foul taint" (HE I. 17).

19 Henceforth indicated as Boethius followed by verse or page number. All quotations are taken from Godden, Irvine, The Old English Boethius. I use here throughout the parallel Modern English translation that accompanies the Old English text taken from this edition. 
than God's law] (Meter 1, 40-41). In Old English religious poetry, gedwola is often associated with the devil's pride and his refusal to recognised God as his superior. Here, Alaric "gedwola" is associated with the crime of murdering Pope John. Arian heresy is here associated with rejection of the faith and rebellion against the highest authority uses vocabulary that in Old English religious verse is associated with Satan. The pope's martyrdom tops the representation of Theodoric empire as a success of translatio imperii but a failure in translatio studii.

In the proem, Alaric is an antagonist, while Boethius is a persecuted hero. Boethius of the Old English adaptation comes across as an outspoken opponent of Alaric's tyrannical denunciation of the faith, which brings about the senator's affliction. While in Consolatio Boethius refutes the allegations of his involvement in the plot to overthrow Theodoric, in the proem, he comes across as the instigator of the rebellion against the unjust ruler.

Wæs him on gemynde mæla gehwilce

Yfel and edwit thæt him el-ðeodge

Kyningas cyðdon; wæs on Creacas hold,

Gemunde para ara and eald-rihta

pe his eldran mid him ahton longe,

Lufan and lissa. Angan pa listum ymbe

ðencean pearflice hu he ðider meahte

Crecas oncerran, pæt se casere eft

Anwald ofer hi agan moste.

Sende ærend-gewrit eald-hlafordum

Degelice, and hi for drihtne bæd

Ealdum treowum ðæt hi æft to him

Comen on pa ceastre, lete Creca witan

Rædan Rom-warum, rihtes wyrðe

Lete pone leodscipe. Ба pa lare ongeat

Đeodric Amuling and pone pegn oferfeng,

Heht fæstlice folc-gesiðas

Healdon pone here-rinc. Wæs him hreoh sefa,

Ege from tham eorle. He hine inne heht

On carcernes cluster belucan.

He [Boethius] bore in mind each of the evil and the contempt that the foreign kings showed them. He was loyal to the Greeks. He remembered the honours and ancient rights as well as the love and the favours which his predecessors had entertained for a long time. Then 
he started to consider carefully how it was possible for him to bring back the Greeks to the city and let the emperor have rule over them again. Secretly, he sent a letter to his former lords, insisting that they should return to the empire and that the Greeks should rule Romans and that the Romans should be allowed to have their due rights. Then Theodoric Amaling heard about this and seized his warrior. His mind was troubled, he was afraid of the nobleman. He ordered him to be imprisoned (Meter 1, 54-84).

Although by medieval standards tyrannical rule was often excused as a deserved scourge for society's sin and a divinely instituted instrument of just punishment, Theodoric is actually the embodiment of injustice and irrational exercise of power. He is also evil by the standards maintained in secular heroic poetry, with which the audience of Boethius must have been familiar; Alfred himself was reported by Asser to have indulged in reading vernacular poetry in his youth. In Beowulf, for instance, Scyld Scefing rouses his neighbours' fear: "egsode eorlas" [terrifies princes] (1.6). ${ }^{20}$ These princes, whom this ancestor of Hrothgar's terrifies, represent foreign nations rather than his own subjects; for the latter, he acts in the capacity of a protector. By these standards, Theodoric acts as an abusive tyrant who disregards justice and is, in effect, sharply contrasted to Boethius, who emerges as a man of principles even as he defies Theodoric's royal authority. Theodoric's tyranny is at its highest when he displays the utmost disregard for the spiritual authority of Rome, as not only does he usurp power, but also infects Rome with a heresy that had been held as particularly contemptible in Anglo-Saxon writings before Alfredian translations; David Pratt suggests that Theodoric's “description as an 'Arian heretic' may depend on the Liber Pontificalis or Bedes Martylology". ${ }^{21}$

The proem provides a cultural context for understanding the Old English Boethius as a political treatise that is not merely a didactic monastic reflection on the limitations of kingship, but, first and foremost, one that contests secular notions of legitimacy of royal power in the very terms that Rita Copeland locates in medieval practices of vernacular translation. The Old English Boethius supplies a programme of correctio that rivals the myth of origins, the primal factor in determining the legitimacy of rule True kingship, in Boethius, is achieved through the cultivation of virtue rather than contesting legitimacy to power through inventing and perpetuating a myth of origins. Exercise of power in Boethius is a function of exercising wisdom. The prerequisite for the ruler's successful management of his subjects is the rule over himself. Alfred

20 The quotation is taken from R. D Fulk, Robert E. Bjork, John D. Niles, eds., Klaeber's Beowulf, the fourth edition (Toronto: University of Toronto Press, 2008). The translation from Old English to modern English is mine.

21 Pratt, The Political Thought, 282. 
turns the commonplace into an important ideological statement. "Se anwald ne deð awiht godes, /gif se wel nele pe his geweald hafað" [power does not give one anything good if a person who has it does not have a good will] (Meter 9, 62-63). Kingly authority does not only derive from military prowess (which was quite essential in times of Viking invasion and the formation of the Viking kingdom of York). Kingship derives its authority from self-knowledge that makes possible the cultivation of four cardinal virtues. ${ }^{22}$ Alfred makes these virtues synonymous with wisdom, as the personified wisdom with whom Boethius discourses embodies them: "Swa swa wisdom is se hehsta cræft and he hæfð on him feower oðre cræftas; para is an wærscipe, oðer gemetgung, ðridde is ellen, feorðe rihtwisnes" [So wisdom is the highest virtue and it has within it four other virtues: one of those is prudence, the second temperance, the third fortitude, the fourth justice] (Prose 14, p. 160). Possession of these virtues endows the individual with self-control: "Se pe wille anwald agon ðonne sceal he ærest tilian /pæt he his selfes on sefan age /anwald innan, by læs he æfre sie his unpeawum eall underðyded" [he who wishes have power must first strive to control his own " (Meter 16, 1-3).

While the model of good kingship provided by the Old English Boethius is a vernacular addition to the source text, the Alfredian adaptation reinforces a hectoring denunciation of the worldly power as inherently corrupted. It is notable, however, that the notion of power in the Old English Boethius comes under scrutiny from the broad focus that the adaptation provides on the notion of cræft. Nicole Guenther Discenza argues that the Alfredian notion of craft found in the Old English Boethius carries the meaning of virtue and locates in this word "a shift from the accepted meanings", as "Alfred not only uses it in the sense of spiritual or mental excellence more than any other extant writer, he also uses it specifically to mean virtue". ${ }^{23}$ Discenza makes a case that "Alfred unites the concept of power, skill, and virtue in one word, thus underscoring one of the main themes of the text linguistically". ${ }^{24}$

This word, as shall be argued here, makes for an important juxtaposition, craft being thrown into sharp relief against anwald. The political theme of Boethius is

22 As the four cardinal virtues are absent from Boethius's Consolatio Philosophae, Paul Szarmach studies possible sources for the theme in Old English Boethius and argues persuasively that the Old English author is likely to have worked independently from either commentaries on Consolatio, many of which call up the Christian idea of cardinal virtues, or from a substantial body of early medieval texts, whether insular or continental, in which they are called up. Paul Szarmach, "Alfred's Boethius and the Four Cardinal Virtues" in: Alfred the Wise: Studies in Honour of Janet Bately on the Occasion of her Sixty-Fifth Birthday, eds. Jane Roberts, Janet L. Nelson (Cambridge: D. S. Brewer, 1997), 233.

23 Discenza, The King's English, 108-109.

24 Ibidem, 112. 
that cultivation of self is a remedy against the corruptive nature of power. As "se eorðlica anweald næfre ne sæwð pa cræftas as licð and gadrað unðeawas" [the earthly power never sows virtues, but gathers and amasses vices] (Prose 14, p. 156). Æhta, weorpscipe, anwald, gielp, woruldlust are five worldly felicities and power is included among them. Wisdom quotes Plato's opinion that "nan anweald nære riht butan rihtum peawum" [no power would be right without right virtues] (Prose 3, p. 16). Meter 4 records Mod's lament over worldly injustice that privileges the wicked: Sittap yfele men giond eorb-ricu /on heah-setlum, halige trhiccap /under heora fotum" [Throughout earthly kingdoms the wickedest sit on high thrones, trample the holy under their feet] (Meter 4, 37-39). Mod contradicts Wisdom's consolation that there is no rule without virtue, pinpointing that "Unrihtwise eallum tidum /habbad on hospe pa pe him sindon /rihtes wisran, rices wyrðran" [At all times the unjust hold in contempt those who are wiser about justice than they are, and more worthy of power] (Meter 4, 43-45). The theme of the corruptive nature of power and worldly honour is picked up again in Prose 8 and Meter 9. Wisdom associates power with ofermod [pride] (Prose 8, p. 84). Wisdom reiterates an argument that he earlier used in connection to wealth: "Forpæm the se anwald næfre ne bið good buton se good sie pe hine hæbbe" [Power is never good unless the person who has it is good] (Prose 8, p. 84). Earthly power inculcates vices rather than virtues in the mind (Prose 14, p. 156). Anwald, worldly authority is repudiated as corrupted by libido dominandi. Theodoric is not the only example of an emperor who fails to embody virtue. The pair of Nero and Seneca counterpoint Theodoric and Boethius (Prose 15, p. 170). It is notable that Alfred's Boethius represents temporal power as weak and prone to intellectual errors as well as moral lapses.

In conclusion, the major implication that emerges from the discussion of royal power in the Old English Boethius is that the text advances a model for the rectitude and Christian reform of kingship. It does so by contesting the traditional genealogy of royal power, supplanting it with an idea for an ethical origin of royalty. Theodoric is not presented by the Old English author as epitome of kingship worth emulation. Not only is his rule is seen in Boethius as a travesty of how royal power should be exercised, but also it threatens the continuity of Rome's Christian Romanitas. Wisdom's critique of secular author relies on a model of kingship that is commensurate with the Christian idea of translatio studii et imperii. Through promoting cultivation of self rather than of the ancestral memory, the Old English Boethius formulates a programme of correctio for earthly rule and presents Alfred as king and teacher. 


\section{References}

Bately, Janet. The Old English Orosius. London: Oxford University Press, 1980.

Bately, Janet. "Did King Alfred Actually Translate Anything”. Medium Aevum 78 (2008), 2: 189-215.

Brooks, Nicholas. Anglo-Saxon Myths: State and Church 400-1066. London and Rio Grande: The Hambledon Press, 2000.

Carruthers, Bob. The Anglo-Saxon Chronicle. Barnsley: Pen and Sword Books Limited, 2013.

Copeland, Rita. Rhetoric, Hermeneutics, and Translation in the Middle Ages: Academic Traditions and Vernacular Texts. Cambridge: Cambridge University Press, 1991.

Discenza, Nicole Guenther. "The Paradox of Humility in the Alfredian Translation", Studia Neophilologica 75 (2003): 44-52.

Discenza, Nicole Guenther. The King's English: Strategies of Translation in the Old English Boethius. New York: State University of New York Press, 2005.

Discenza, Nicole Guenther. "Alfred the Great and the Anonymous Prose Proem to the Boethius." The Journal of English and Germanic Philology 107 (2008): 57-76.

Fulk, R. D, Robert E. Bjork, John D. Niles, ed. Klaeber's Beowulf. The fourth edition. Toronto: University of Toronto Press, 2008.

Godden, Malcolm, Susan Irvine, red. The Old English Boethius: An Edition of the Old English Versions of Boethius's De Consolatione Philosophae. 2 vols. Oxford: Oxford University Press, 2009.

Godden, Malcolm, Susan Irvine, red. Old English Boethius with Verse Prologues and Epilogues Associated with King Alfred. Cambridge, Ma: Harvard University Press, 2012.

Harris, Stephen J. Race and Ethnicity in Anglo-Saxon Literature. New York and London: Routledge, 2003.

Lerer, Seth. Literacy and Power in Anglo-Saxon Literature. Lincoln and London: University of Nebraska Press, 1991.

Moisl, Hermann “Anglo-Saxon Royal Genealogies and Germanic Oral Tradition”. Journal of Medieval History 7 (1981): 215-248.

Pratt, David. The Political Thought of King Alfred the Great. Cambridge: Cambridge University Press, 2007.

Sedgefield, Walter John. King Alfred's Old English version of Boethius De Consolatione Philosophae. Oxford: Clarendon Press, 1899.

Szarmach, Paul E. "Alfred's Boethius and the Four Cardinal Virtues". In: Alfred the Wise: Studies in Honour of Janet Bately on the Occasion of her Sixty-Fifth Birthday, eds. Jane Roberts, Janet L. Nelson. Cambridge: D. S. Brewer, 1997.

Stanton, Robert. The Culture of Translation in Anglo-Saxon England. Cambridge: D.S. Brewer, 2002.

Sweet, Henry. An Anglo-Saxon Reader in Prose and Verse. Oxford: Clarendon Press, 1888. 


\section{Summary}

Wood, Michael. The Making of King Athelstan's Empire: an English Charlemagne. In: Patrick Wormald (ed.), Ideal and Reality in Frankish and Anglo-Saxon Society 1983, 250-272. The purpose of the article is to elucidate the Old English Boethius, Old English translation of Boethius's Consolation of Philosophy, the translation of which is attributed to King Alfred the Great (849-899 A.D). The article provides a special focus on the versified proem to the prosometric version of Boethius. The proem, arguably, represents a view of Ostrogothic Kingdom of Theodoric that counters the notion of Germanic myth of origin pervading Anglo-Saxon textual culture and the memory of Theodoric as Germanic ruler of Rome that is evident in Old English poetic tradition. The Old English Boethius, arguably, contests the established tradition to promote a Christian grooming of the Anglo-Saxon notion kingship in keeping with the Alfredian programme of cultural reform.

Keywords: The Old English Boethius, Alfred the Great, Old English literature, Early Medieval Literature, English Literature

\section{KRÓLESTWO OSTROGOTÓW W STARO-ANGIELSKIM PRZEKŁADZIE O POCIESZENIU, JAKIE DAJE FILOZOFIA BOECJUSZA A GERMAŃSKI MIT O POCHODZENIU W ANGLO-SASKIEJ ANGLII}

\section{Streszczenie}

Celem tego artykułu jest omówienie staro-angielskiego przekładu traktatu Boecjusza O pocieszeniu, jakie daje filozofia. Jego staro-angielski przekład jest przypisywany królowi Alfredowi Wielkiemu (849-899 A.D.). Artykuł poświęca szczególną uwagę wersyfikowanemu wstępowi do utworu w przekładzie staro-angielskim, w którym przedstawione zostały dzieje królestwa Ostrogotów za panowania Teodoryka Wielkiego z dynastii Amalów. Ten poetycki wstęp jest w całości inwencją staro-angielskiego tłumacza, a sposób przedstawienia Teodoryka i jego polityki kontestuje anglosaskie pojęcie o germańskich początkach narodu angielskiego a także historyczne przekazy o Teodoryku, germańskim władcy Rzymu, w poezji staro-angielskiej. Artykuł stawia tezę, że staro-angielski przekład traktatu kontestuje tradycję i uzupełnia ją o schrystianizowaną definicją władzy królewskiej, która jest zgodna z programem reformy kulturowej propagowanej przez Alfreda Wielkiego oraz jego następców.

Słowa kluczowe: staro-angielski przekład Boecjusza O pocieszeniu, jakie daje filozofia, Alfred Wielki, literatura staro-angielskiego, literatura średniowieczna, literatura angielska 
